ACTA THERIOLOGICA

Vol. 23,36 : $527-539,1978$

\title{
Diurnal Rhythm of the Skeleton Growth of Some Rodent Species:
}

\author{
Galina A. KLEVEZAL \& Marek GĘBCZYŃSKI
}

\begin{abstract}
Klevezal G. A. \& Gebczyński M., 1978: Diurnal rhythm of the skeleton growth of some rodent species. Acta theriol., 23, 36: 527-539. [With 1 Fig. \& 3 Tables]

Experiments were carried out on four species of rodents: Wistar rats, bank voles, European pine voles and field voles. Oxytetracycline (OTC) was injected at different times of the night and day in doses from $10-20 \mathrm{mg} / \mathrm{kg}$ of body weight and the animals killed 6 to 12 hours later. Intensity of yellow fluorescence was estimated in ultraviolet light in the following bones: skull, fore and hind leg and spine, as a measure of the rate of OTC incorporation into the growing bone. It was found that intensity of incorporation in the bones is not uniform throughout the course of 24 hours, but is higher during the active period of the animal's diurnal rhythm. This provides grounds for assuming that the diurnal rhythm of skeleton growth is divided into periods of varying rate of growth.
\end{abstract}

[Inst. Develop. Biol USSR Acad. Sci., 117334 Moscow, 26 Vavilov St.; Mammals Res. Inst., Polish Acad. Sci., 17-230 Białowieża, Poland]

\section{INTRODUCTION}

It is impossible to examine growth regulation without obtaining information on its rhythms, primarily diurnal rhythm and rhythms with a shorter periods ( $\mathrm{M}$ in a \& Kleve zal, 1976). It is, however, these very rhythms about which least is known. There have been few data up to the present pointing to the existence of diurnal growth rhythms in mammals. Among these we may include information on rhythm of increase in body weight in rat embryos on the 19th-22nd day of development (B a r r, 1973), linear increase in the long bones of the limbs in rabbits ( $\mathrm{H}$ anss on et al., 1974), and circadian and also circannual growth rate of the condilar cartilage (O udet \& Petrovic, 1977). Parameters of body length and weight are not suitable for estimating diurnal growth rhythms, on account of the very slight increase during this interval of time, and consequently the considerable possibility of error. More accurate data on growth 
are obtained by measuring skeleton growth, since the changes taking place can be grasped with a greater degree of precision.

Antibiotics of the tetracycline group have been used to observe skeleton growth rate (H a rris, 1960; Hansson, 1967; S oni \& $\mathrm{M}$ e s s e r, 1970). It was therefore assumed that they might prove useful for studies on diurnal rhythms of skeleton growth. Tetracyclines combine with $\mathrm{Ca}^{++}$and actively enter into the new growing bone. In this way all new growing bone acquires the capacity for yellow fluorescence in ultraviolet light (UV), distinctly different from the white autofluorescence of non-growing parts of bones $(\mathrm{M} \mathrm{il} \mathrm{c} \mathrm{h}$ et al., 1958; 1961; H arris et al., 1962; I bs en \& Urist, 1964). Incorporation of tetracycline in bone tissue does not depend on the way in which it is introduced into the organism ( $\mathrm{M} \mathrm{ilch}$ et al., 1958). This substance is not very toxic and, for instance after intraperitoneal introduction $\mathrm{LD}_{50}$ for mice, amounts to about $330 \mathrm{mg} / \mathrm{kg}$, and for rats $320 \mathrm{mg} / \mathrm{kg}$ (C unningham et al., 1953). Doses below $20 \mathrm{mg} / \mathrm{kg}$ are considered completely harmless (I bs en \& Urist, 1964).

Tetracyclines appear in tissues 30 minutes after their intraperitoneal introduction and remain in soft tissues and blood for 6-8 hours (M i l c h et al., 1958; T a p p, 1966). Tetracycline excretion rate depends on the method of introduction into the organism and most probably also on the type of substance used ( $\mathrm{H}$ an s s o n, 1967).

$\mathrm{H}$ a n s s on et al. (1974), in studies on the diurnal rhythms of growth of the long bones of rabbit limbs, injected tetracycline intravenously every 6 hours and measured on sections the growth of bone tissues between neighbouring lines of tetracycline. Klevezal (1976) used a different method, injecting half of the rats from an experimental group with tetracycline during one time of the day, and the other half at a different time of the day, killing all the animals 12 hours after injection. It was found that intensity of fluorescence and area of the fluorescent surfaces of the skeleton in rats treated in the evening is greater than in rats given tetracycline in the morning. Thus growth appears to be more rapid during the evening and night. This method is technically simple and permits of evaluating the relative intensity of growth at different times of the 24-hour period in both flat and long bones in the skeleton.

The purpose of the study presented here was not only to investigate the characteristics of diurnal growth rhythms of the skeleton in four species of rodents, but also to carry out a comprehensive evaluation of the method used. For this reason, in addition to examining the rate at which tetracycline is deposited at different times of the day, measurement was also made of the rate of its excretion in urine. Examination 
was additionally made of the relation between intensity of tetracycline fluorescence and the time the animals were killed after injection, and also the effect of the dose of this substance administred on the results obtained; in addition the relation existing between fluorescence level and the age of the animals examined was investigated.

\section{MATERIAL AND METHODS}

Wistar rats (from the laboratory colony of the Academy of Medical Sciences of USSR, Moscow) and three species of voles [12-14 inbred laboratory generation of Clethrionomys glareolus (S chreber, 1780), Microtus agrestis (L in naeus, 1781), Pitymys subterraneus (de Sély s-L ong champs, 1835) from the laboratory colony of the Mammals Research Institute, Białowieża, Poland] were used for the studies.

In experiment individuals belonging to the given litter were divided into two groups ( $a$ and $b$ ), and each of the groups was labelled with tetracycline at 12-hour intervals (Table 1). Oxytetracycline (OTC) was injected intramuscularly in doses of $10-20 \mathrm{mg} / \mathrm{kg}$ and the animals killed either 6 or 12 hours later. The dose of OTC and time between injection and killing was always the same for all the individuals in a given litter. Excretion of OTC from the organism was determined on the basis of tetracycline yellow fluorescence in the urine. Studies were made in the separate series of experiments on the effect of OTC doses within limits of 10 to $110 \mathrm{mg} / \mathrm{kg}$ on the results abtained. In addition the relation between fluorescence intensity and the time which elapsed between injection and animal's death was investigated. For this purpose OTC was injected into 70 rats from 8 litters, killing $2-3$ individuals from each group after $6,18,24$ and 67 hours.

The rodents' skeletons were cleaned after boiling for a short time and stored dry until required for analysis. The following parts were taken for analysis: skull together with the mandible, the long bones of the fore and hind limbs and $2-3$ vertebrae. UV light was supplied by an OI-18 lamp (USSR) and/or analytical quartz lamp (Poland).

When making visual comparisons of areas and intensity of yellow fluorescence of the bones the individuals from one litter were given consecutive numbers and compared in pains - each with each other. The observer did not know which of the pairs includes animals from the same group and which includes animals from different groups. The pairs consisting of the animals from different groups were next revealed and the sign test was used, i.e. one of the methods of non-parametric statistics ( $\mathrm{Urbach}, 1963$ ), estimating the significance of differences between groups injected at different times of the day.

The photometric method was used to make a quantitative estimate of yellow fluorescence intensity. The skull of rodents in both groups of the same litter were photographed from the top and from the bottom in UV light on a film developed at the same time, then intensity of fluorescence from bones and sutures estimated by means of an MF-4 microphotometer (USSR).

\section{RESULTS}

Yellow fluorescence in UV light was found in all the animals examined in all the parts of the skeleton observed. The bones of the 
base of the skull, palatal bones, the frontal processes of the intermaxillary bones, the zygoma and sutures of the dome of the skull exhibited the most intensive fluorescence.

\subsection{Comparison of Pairs and Photometric Estimate}

In visual comparisons of pairs the observer alloted one of three possible estimates: equal $(0)$, more $(+)$ and less $(-)$. The number of pluses and minuses were counted for analysis of significance, while zero estimates were excluded from the comparison (Table 1). Significant

Table 1

Comparison of the level of yellow fluorescence of the skeleton in four species of rodent injected with oxytetracycline at different times of day.

S - statistically significant, NS - not significant.

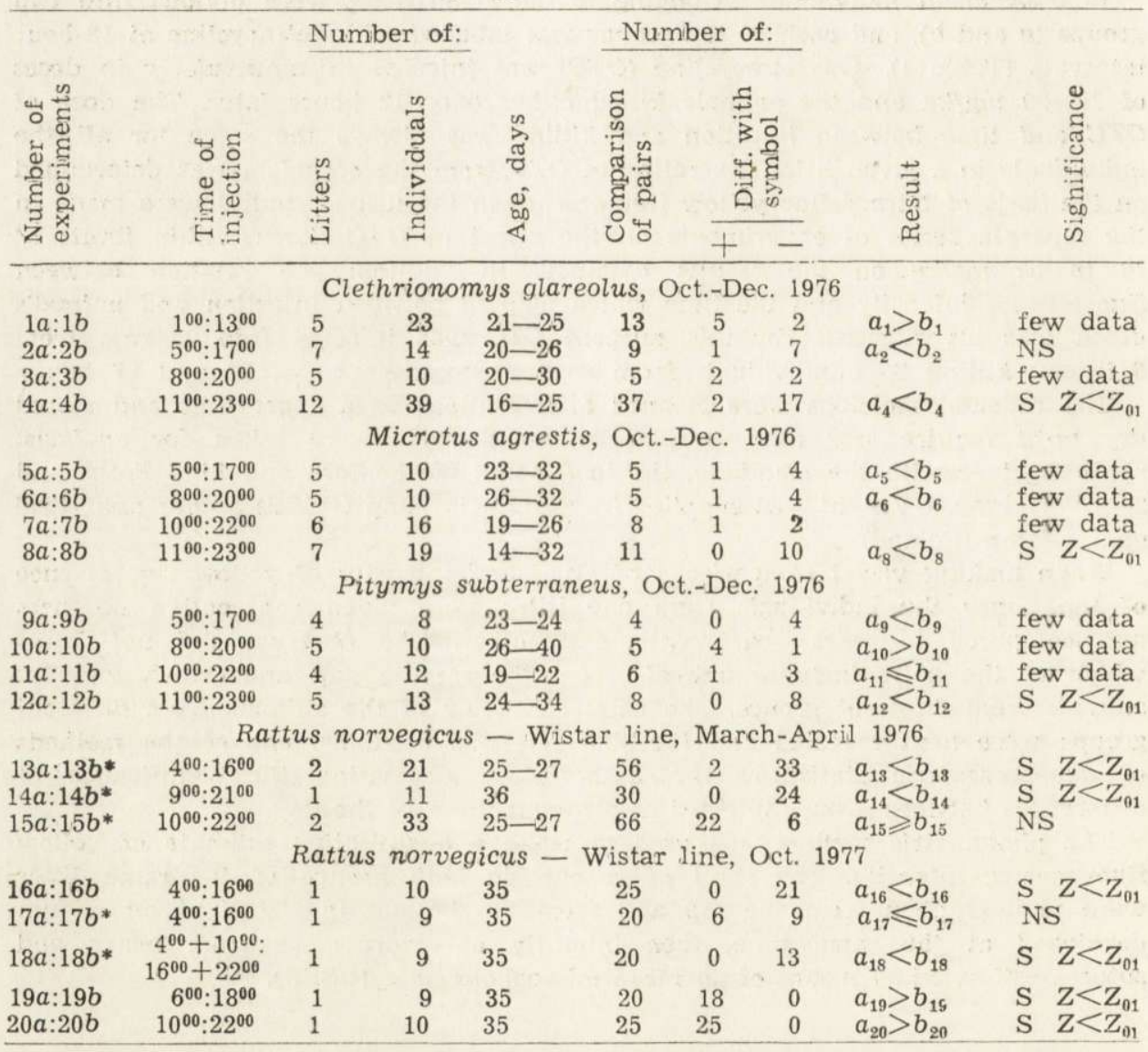

Differences with the symbol ( + ) indicate that the fluorescence level of bones of group $a$ individuals is higher than that of group $b$ individuals; $(-)$ indicates that fluorescence level of individuals in group $b$ is higher than that of individuals in group $a$.

* Animals killed 12 hours after injection, in all other cases they were killed 6 hours after injection. 
differences were obtained in 6 out of 8 series of experiments on Wistar rats and in 3 out of 12 series of voles. In the second case in 7 series the material was too scanty to estimate significance of differences.

An estimate was also made of the agreement obtained in repeats of visual assessments. The agreement of estimates given by two observers in the first month after the experiment was $92 \%$. After 10 months the first observer obtained $76 \%$ agreement with his own estimates, and $88 \%$ agreement of his estimates with those of the second observer. In all, in 9 cases out of 184 repeat observations results were overesti-

Table 2

Results of photometric quantitative estimate of yellow fluorescence intensity for series No. 13 (see Table 1).

\begin{tabular}{|c|c|c|c|c|c|}
\hline & $\begin{array}{r}a_{13} \\
\text { Mean; }\end{array}$ & S.D. & $\begin{array}{l}b_{13} \\
\text { Mean; }\end{array}$ & S.D. & Student $t$ test \\
\hline $\begin{array}{l}\text { Different parts of skull * } \\
\text { Bones of base of skull }\end{array}$ & $\begin{array}{l}417 \\
218\end{array}$ & $\begin{array}{l}47^{* *} \\
13^{* *}\end{array}$ & $\begin{array}{l}503 \\
268\end{array}$ & $\begin{array}{l}57^{* *} \\
25^{* *}\end{array}$ & $\begin{array}{l}P<0.05 \\
P<0.01\end{array}$ \\
\hline
\end{tabular}

* Measurement of fluorescence of processi palatini ossis maxillare, bullae tympanicae (right and left), processi frontales ossis praemaxillare (right and left) and coronal and lambdoidal sutures.

** In units of logarithmic scale of galvanometer.

mated (estimated as + instead of 0 ) and in 32 underestimated (-given instead of 0 ). This may have been due to reduction in OTC fluorescence when dry bones were stored for a long time.

It was anticipated that the evaluation of differences could be carried out by the photometric method, but neither choice of films very sensitive to the yellow part of the spectrum nor choice of filters made it possible to obtain a sharply-defined boundary between yellow fluorescence and white autofluorescence of non-growing parts. It was therefore only possible to assess fluorescence intensity of different bones or defined parts, but not possible to calculate the area of the fluorescent parts. Despite these difficulties a quantitative estimate was made for series No. 13 of the yellow fluorescence intensity of different parts of the skull and its base. The data obtained indicate that quantitative differences are significant (Table 2), as are also the differences estimated using the sign test (Table 1).

\subsection{Relation between Fluorescence of the Skeleton and Time of Injecting OTC}

In all three species of voles examined in autumn individuals injected at $23^{\circ 0}$ have significantly greater fluorescence of the skeleton than individuals labelled at $11^{\circ 0}$ (Series No. 4, 8, 12-Table 1). No significant differences were obtained between groups marked with OTC at other times of the day, which to same extent can be explained by the small 
numbers in the groups. In both $C$. glareolus and M. agrestis, however, yellow fluorescence was greater after injections made between $17^{00}$ to $01^{00}$ than after injections made between $5^{00}$ and $13^{00}$. The picture was different in the case of $P$. subterraneus, since the skeleton of individuals injected at $08^{00}, 17^{00}$ and $23^{00}$ exhibited greater fluorescence than those injected at $05^{00}, 11^{00}$ and $20^{\circ 0}$.

Wistar rats were examined in spring and autumn. It was found that in spring, with evening injection times of $16^{00}$ and $21^{00}$, bone fluorescence was greater than in groups injected in the morning at $04^{00}$ and $09^{00}$ (series No. 13, 14-Table 1). Comparison of groups $a$ and $b$ from series no. 15 permitted of assuming that increased fluorescence was to be expected after injection at $10^{\circ 0}$. The difference was very distinct and unmistakable in series no. 14, in which the animals were labelled at $09^{00}$ and $21^{\circ 0}$. In experiments made in autumn (series No. 16-20) the most distinct differences were those between individuals injected at $10^{00}$ and $22^{00}$, in the first case the yellow fluorescence was much more developed. It was more developed also in the individuals injected at $16^{00}$ in comparison with $18^{00}$; and in those injected at $16^{00}$ in comparison with $04^{00}$. The differences were significant in all cases. Skeleton fluorescence was therefore greater in animals injected during the day $\left(06^{00}, 10^{00}\right.$ and $\left.16^{00}\right)$ than in those injected in the evening and early morning $\left(18^{00}, 22^{00}\right.$ and $04^{00}$; Fig. $\left.1 \mathrm{a}, \mathrm{b}\right)$.

\subsection{Excretion of OTC in Urine}

In groups of rats injected in the morning and in the evening urine samples were taken on filter paper every hour and intensity of OTC fluorescence evaluated. It was found that fluorescence intensity decreased after 7 hours, later individual variations were too great to estimate the diurnal rhythm of OTC excretion. In certain individuals, both those injected in the morning and in the evening, OTC excretion could be observed even after 12 hours.

In the majority of the experiments the animals were killed 6 hours after injection (Table 1). In voles intensity of OTC fluorescence in the urine was practically uniform during the first and sixth hours after injection, and did not depend on the time of day at which injection took place. Urine samples were taken $15-30$ minutes before the animals were killed in the case of rats in experiments Nos. 16-20. No OTC was found in the urine of 19 individuals out of 46. The degree of yellow fluorescence from the skeleton was compared in pairs of individuals from one litter from groups $a$ and $b$, after selecting pairs with uniform and with different $O T C$ index in the urine. In the first case, out of 24 comparisons, regardless of whether OTC was present. 
in the urine or not, in 23 cases differences were found between groups depending on the time OTC had been injected. In the second case, out of 35 comparisons, in 19 yellow fluorescence of the skeleton was greater in the individual in which OTC had been found in the urine before its
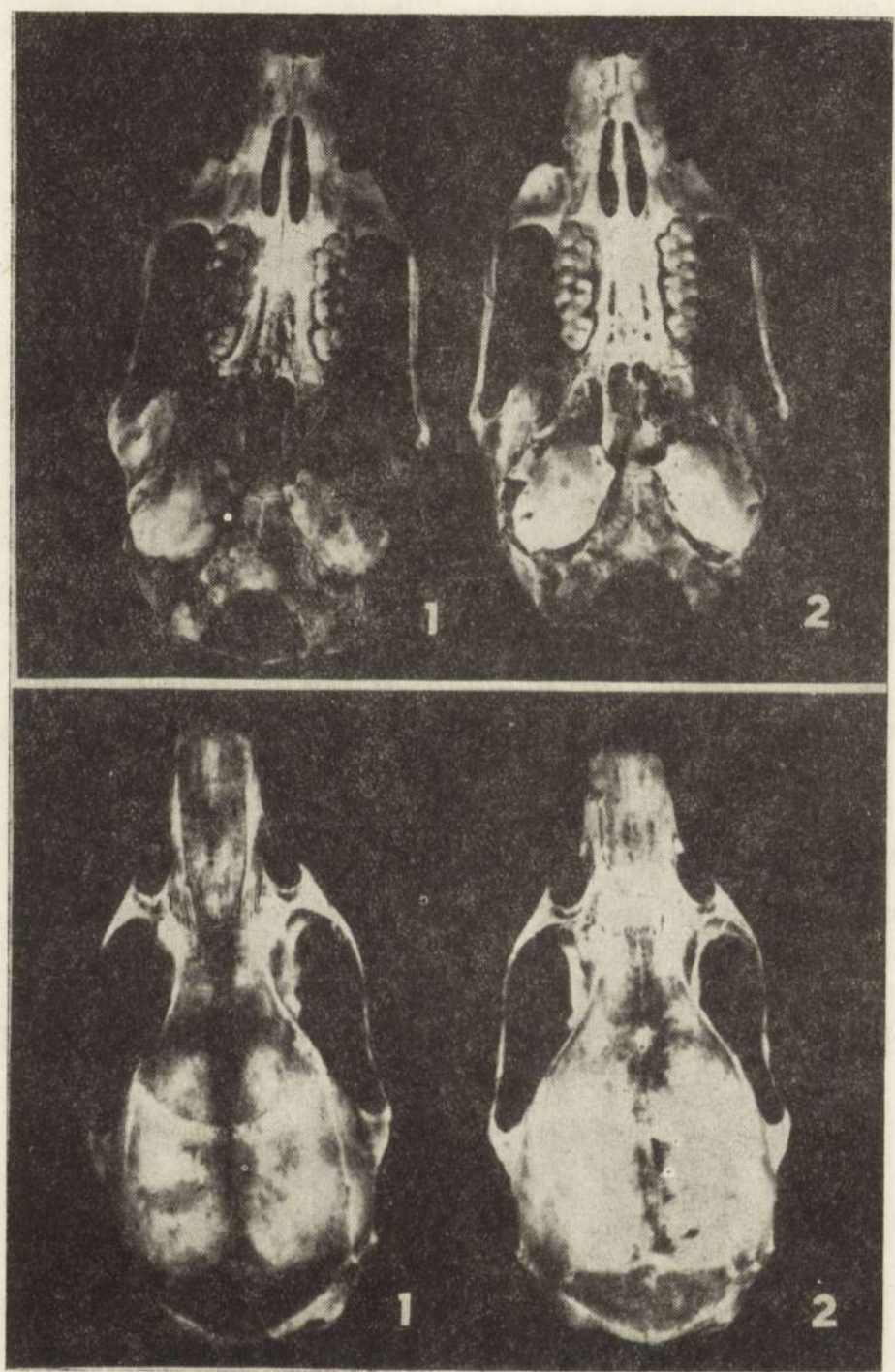

Fig. 1. Fluorescence of the skull of the Wistar rat.

Experiment No. $20 ; 1$ - specimen of group $b, 2-$ specimen of group $a$.

death, and in 11 the opposite. It thus proved impossible to find whether there was a relation between OTC excretion rate in the urine and intensity of yellow fluorescence of the skeleton. 
The results of experiments Nos. 16, 17 and 18 are also evidence of the lack of such relations. Rats from three litters were injected at the same time at $04^{00}$ (groups $a$ ) and $16^{00}$ (groups b). Individuals of the first litter were killed 6 hours later (series 16), of the second litter 12 hours later (series 17) and individuals of the third litter (series 18) were injected again 6 hours after the first injection and killed 6 hours later. In accord with the data given above we can think that in the first and in the third case OTC concentration in the blood was approximately constant from injection to death, during a period of respectively 6 and 12 hours, and that in the second case this concentration decreased during the last 5 hours before the animals were killed. If diurnal differences in yellow fluorescence of the skeleton depended on variations in OTC excretion, then the greatest differences in skeleton fluorescence should be expected to occur in series 17 , in which differences in OTC excretion could appear most distinctly. In fact the reverse result was obtained (Table 1). In series 16 and 18 all differences were of the same direction: individuals from the evening groups exhibited significantly greater fluorescence than individuals from the early morning groups. In series 17 some of the individuals from the evening groups were distinguished by greater fluorescence and some by lesser, but the differences were insignificant.

3.4. OTC Fluorescence in Individuals Killed at Different Times after Injection

Visual comparison of the skeletons of rats from the same litter killed 6,18 , or 24 hours after injection did not reveal any regular differences in intensity and area of fluorescence, but skeleton fluorescence of rodents killed 67 hours after injection was markedly less. This was confirmed in measurements of the most highly fluorescent parts of the skull - the palatal processes of the maxillary bone and tympanic bullae (Table 3).

\section{Table 3}

Intensity of yellow fluorescence of bones in individuals from four litters, depending on interval between oxytetracycline injection and killing the animals.

\begin{tabular}{crrr}
\hline Time after injection, hours & Mean; S.D. & n \\
\hline 6 & $208 ;$ & $21^{*}$ & 8 \\
18 & $209 ;$ & $36^{*}$ & 9 \\
24 & $206 ;$ & $32^{*}$ & 10 \\
67 & $176 ;$ & $63^{*}$ & 10 \\
\hline
\end{tabular}

* In units of logarithmic scale of galvanometer. 


\subsection{Relation between Fluorescence and Dose of OTC}

In series Nos. 1, 7 and 11 OTC was.injected into the animals in each group in amounts of 20,30 , and $50 \mathrm{mg} / \mathrm{kg}$. In the individuals of the same group injected with 20 and $30 \mathrm{mg} / \mathrm{kg}$ practically equal fluorescence of the skeleton was observed. Comparing with them animals injected with $50 \mathrm{mg} / \mathrm{kg}$ exhibited significantly greater intensity of fluorescence. Nevertheless the relation between groups $a$ and $b$ was uniform in all cases.

\subsection{Relation between Degree of Fluorescence of the Skeleton and Age of} Individuals

After injecting the same dose of OTC at the same time of the day, intensity and area of fluorescence from the bones of the skeleton decreased with increasing age of the animals. This was observed in the case of field voles from 14 and 34 days old (series Nos. 4, 8, 12-Table 1). As far as the material at our disposal permits of reaching a conclusion, it is that the character of diurnal changes remains the same regardless of the age of the animals examined, e.g. in series No. 8 among 14-day old individuals of $M$. agrestis (2 pairs) and 18-day old (2 pairs), 23-day old (1 pair), 27-day old (1 pair) and 32-day old ( 2 pairs) yellow fluorescence of the skeleton in individuals injected at $23^{00}$ was greater than in those injected at $11^{00}$. In $P$. subterraneus also the result was similar in all pairs of series No. 12, even though the pairs varied in age from 24 to 34 days.

\section{DISCUSSION}

Specially planned studies ( $\mathrm{Harr}$ is et al., 1962) were aimed at obtaining a reply to the question as to whether tetracycline labels each growing bone and whether it labels growing bone only. The animals used for the experiments were dogs injected intravenously with doses varying from 30 to $100 \mathrm{mg} / \mathrm{kg}$. It was found that tetracycline was incorporated in all growing bones of the skeleton and in addition, with larger doses, a certain amount also combined with parts of the bone which were not growing and were only slightly mineralized, producing a diffusive fluorescence there. $\mathrm{H}$ a r r is et al. (1962) also found that in animals killed immediately after injection passive deposit of tetracycline was observed on the non-growing surfaces.

In our experiments we used small doses of tetracyline and therefore there was no fear of tetracycline becoming incorporated in non-growing slightly mineralized parts of the bones. It was, however, feared that the 6-hour interval between injection and killing the animals was too short a time for the OTC not incorporated into the bone and deposited 
on its surface to be excreted. The experiments made on Wistar rats showed, however, that fluorescence was uniform in animals killed 6, 18 and 24 hours after injection (Table 3 ). It was slightly lower in animals killed 67 hours after injection, which is understandable, since during this time a certain amount of new unlabelled bone had formed above the bone tissue labelled with tetracycline.

Yellow fluorescence of the skeleton in our experiments was therefore considered as fluorescence of OTC incorporated into the newlyformed growing bone tissue. In all the species examined a significant diurnal rhythm of quantitative OTC incorporation and area of its incorporation was observed. This can be explained cither by diurnal variations in the growth rate of the skeleton or similar rhythm of tetracycline excretion from the organism. In the second case with constant growth rate of bone during the 24-hour period, less OTC would be deposited in the skeleton during the period of its rapid excretion, but in such a case it would only be the intensity of fluorescence, but most certainly not the fluorescent area, which would vary. Investigation was made of OTC excretion rate in urine in our experiments and it was found that there were neither distinct diurnal differences nor a relation between the periods of OTC excretion and intensity of skeleton fluorescence. The diurnal rhythm of OTC incorporation in the skeleton therefore depends only on variations in the rate of skeletal growth.

In rabbits examined when 5 weeks old significant differences were observed in growth of the long bones, which grow most slowly in the evening ( $\mathrm{H}$ ans son et al., 1974). Our data reveal diurnal rhythm in all 4 species of rodents examined. M. agrestis and C. glareolus are distinguished by growth during the night hours when their locomotor activity is very high (Erkinaro, 1961; S a int-Girons, 1966). Similarly in $P$. subterraneus the agreement of the periods of intensive OTC incorporation twice a day with their bimodal activity pattern is striking (Gę bczyński, 1964). Some data (D mitriev, 1975; Er$\mathrm{dak}$ ov et al., 1975) show that Wistar rats are evenly active over the whole 24-hour period. Our results, however, show that skeleton growth is not even and that in autumn the maximum occurs at $06^{00}-16^{00}$, and the minimum from $18^{\circ 0}$ to $04^{\circ 0}$. In spring, on the other hand, rate of growth is highest during the evening hours, as opposed to morning hours. The way in which the experiments were made in spring and autumn is not fully comparable, but even -so they point to seasonal variations in growth rhythms in the same way as has been observed in relation to many other physiological characteristics (A s ch off, 1969).

The method we used permits of obtaining a summarised estimate of growth for a period of 6 or 12 hours depending on the length of the 
interval between injecting and killing the animal. A single intraperitoneal injection of tetracycline labels the calcium deposited in newlyforming bone for about 8 hours ( $\mathrm{T}$ a p p, 1966), 10 hours (S m e e nk et al., 1965 after P e t ko et al., 1970) or even 12 hours (P e t ko et al., 1970). It is thus impossible to grasp shorter ultradial rhythms.

The existence of such rhythms would appear probable since diurnal rhythms of growth hormone concentration in the blood and pituitary (M u lle r et al., 1970; B a horski et al., 1969; Esber et al., 1976), and rhythm of 3 hours concentration of this hormone in blood ( $\mathrm{T}$ a $\mathrm{n}$ nenbaum, Martin \& Cole, 1976; Walloughby et al., 1976; Tannenbaum \& Martin, 1976) have been found in rats. It may be that the diurnal rhythms of the skeleton growth are formed on the base of the ultradiurnal rhythms which as yet remain unknown.

In evaluating the method used for studies on diurnal rhythms of skeleton growth it must be emphasised that its chief deficiency is the fact that it is almost impossible to make a quantitative estimate of the phenomenon. It has, however, the advantage of providing an estimate of growth of all bones of the skeleton, it can be used under field conditions and analysis of material is rapid and involves the use of simple apparatus only. It is a method convenient for use in studies of total diurnal rhythm and its intra- and interspecies variations and also seasonal and ecological differences.

Acknowledgements: The authors gratefully acknowledge the skillful help given by M. S. Vladimirskaja and V. I. Podmarev (Inst. Dev. Biol., Moscow) and J. Lipińska (Mammals Res. Inst., Białowieża). We also profited by discussion with Dr. M. V. Mina (Inst. Dev. Biol., Moscow).

\section{REFERENCES}

1. Aschoff J., 1969: Phasenlage der Tagesperiodik in Abhängigkeit von Jahrenszeit und Breitengrad. Oecologia (Berl.), 3: 125-165.

2. Bahorsky M. S. \& Bernardis L. L., 1969: Circadian fluctuation in tibia cartilage assayable pituitary homogenates of fed and starved weanling female rats. Experientia (Basel), 25, 7: 755-756.

3. Barr M., 1973: Prenatal growth of Wistar rats: circadian periodicity of fetal growth late in gestation. Teratology, 7, 3: 283-287.

4. Cunningham R. W., Hines L. R., Stokey E. H., Vessey R. E. \& Y uda N. N., 1953: Pharmacology of tetracycline. Antibiotics Annual 19531954, NY Med. Encycl.: 63-69.

5. Dmitriev J. S., 1975: Sutočnaja ritmika dvigatelnoj aktivnosti krys genetičeski raznyh lini. [In: Sb. „Cirkadnye ritmy čeloveka i životnyh«], Izd. "Ilim«: 274-276. Frunze.

6. Erdakov L. N., Putilov A. A. \& Romashov N. A., 1975: Sravnitelnoe izučenie cirkadnych ritmov aktivnosti gryzunov. [In: Sb. „Cirkadnye ritmy čeloveka i životnyh«], Izd. »Ilim«: 277-278. Frunze. 
7. Erkinaro E., 1961: The seasonal change of the activity of Microtus agrestis. Oikos, 12, 1: 157-163.

8. Es ber H. J., Kuo E. \& B o g den A. E., 1976: Circadian pattern of prolactin and growth hormone levels in female rats of two strains. Lab. Anim. Sci., 26, 2, p. 1: $186-189$.

9. Gębczyński M., 1964: Effect of light and temperature on the 24-hour rhythm in Pitymys subterraneus (de Sél.-Long.). Acta theriol., 9, 9: 125-137.

10. Hansson L. I., 1967: Daily growth in length of diaphysis measured by oxytetracycline in rabbit normally and after medullary plunging. Acta Orthop. Scand., Supp., 101: 1-199.

11. Hansson L. I., Stenström A. \& Thorngren K. G., 1974: Diurnal variation of longitudinal bone growth in the rabbit. Acta Orthop. Scand., 45: $499-507$.

12. Harris W. H., 1960: A microscopic method of determining rates of bone growth. Nature, 188 (4755): 1038-1039.

13. Harris W. H., Jackson R. H. \& Jowsey J., 1962: The in vivo distribution of tetracyclines in canine bone. J. Bone and Jt. Surg., 44 A, 7: 1308 -1320 .

14. I bs en K. H. \& Urist M. R., 1964: The biochemistry and physiology of the tetracyclines: with special reference to mineralized tissues. Clin. Orthopaed. and Related Research, 32: 143-169.

15. Klevezal G. A., 1976: Novyj metod izučenija sutočnyh ritmov rosta. Priroda, 12: 119.

16. Milch R. A., Ra 11 D. P. \& Tobie J. E., 1957: Bone localization of the tetracyclines. J. nat. Cancer Inst., 19, 1: 87--93.

17. Milch R. A., Ra 11 D. P. \& Tobie J. E., 1958: Fluorescence of tetracycline antibiotic in bone. J. Bone and Jt. Surg., 40 A, 4: 897-910.

18. Milch R. A., Tobie J. E. \& Robins on R. A., 1961: A microscopic study of tetracycline localization in skeletal neoplasms. J. Histochem. Cytochem., 9, 3: $261-270$.

19. Mina M. V. \& Klevezal G. A., 1976: Rost životnyh. Analiz na urovne organizma. Izd. „Nauka«: 1-291. Moskva.

20. Muller E. E., Giustina G., Medico D., Pecile A., Cocchi D. \& W a ng King F., 1970: Circadian pattern of bioassyable and radioimmunoassayable growth hormone in the pituitary of female rats. Proc. Soc. Exp. Biol. Med., 135, 3: 934-939.

21. Oudet C. \& Petrovic A., 1977: Circannual growth variations of the mandibular condylar cartilage in the young rat. J. interdiscipl. Cycle Res., 8, 3-4: $338-340$.

22. Petkó M., Földes I. \& Löcsey L., 1970: Fluorescence histological study of bone growth in the rat's epiphyseal cartilage. Acta morphol. Acad. Sci. Hung., 18, 4: $349-357$.

23. Sa int-Girons M. C., 1966: Le rhythme circadien de l'activite chez les Mammiféres Holarctiques. Mem. Mus. Nation. d'Hist. Nat., A, Zool., 40, 3: $101-187$.

24. Soni N. N. \& Messer K. B., 1970: Determination of growth rates by tetracycline-labelling in guinea pig maxillas. Anat. Rec., 166, 4: 569-574.

25. Tapp E., 1966: Tetracycline labelling methods of measuring the growth of bones in the rat. J. Bone and Jt. Surg., 48 B, 3: 517-525. 
26. Tannen ba um G. S. \& Martin J. B., 1976: Evidence for an endogenous ultradian rhythm govering growth hormone secretion in the rat. Endocrinology, 98, 3: $562-570$.

27. Tannenbaum G. S., Martin J. B. \& Cole E., 1976: Ultradian growth hormone rhythm in the rat: effects of feeding, hyperglycemia and insulininduced hypoglycemia. Endocrinology, 99, 3: 720-727.

28. U r ba ch V. J., 1968: Matematičeskaja statistika dla biologov i medikov. Izd. AN SSSR: $1-323$, Moskva.

29. Walloughby J. O., Martin J. B., Renaud L. P. \& Brazeau P., 1976: Pulsative growth hormone release in the rat: failure to demonstratea correlation with sleep phases. Endocrinology, 98: 4; 991-996.

Accepted, March 6, 1978.

Galina A. KLEVEZAL i Marek GĘBCZYŃSKI

\section{DOBOWE RYTMY WZROSTU SZKIELETU U GRYZONI}

\section{Streszczenie}

Doświadczenia przeprowadzone były na 4 gatunkach gryzoni - szczurach laboratoryjnych rasy Wistar, nornicy rudej, darniówce i norniku burym. Zwierzętom wstrzykiwano chlorowodorek oksytetracykliny (OTC) w różnych porach doby i zabijano je po 6 lub 12 godzinach. Następnie obserwowano w świetle ultrafioletowym intensywność żółtej fluorescencji w kościach: czaszki, kończyny przedniej i tylnej oraz kręgosłupa, co stanowi miarę tempa wbudowywania się podawanej substancji w rosnącą kość (Ryc. 1). Intensywność wbudowywania się OTC w kości jest niejednakowa w ciągu doby, co oszacowano zarówno sposobem porównania względnego (Tabela 1), jak i bezwzględnego (Tabela 2). Wzrost szkieletu jest szybszy w okresie aktywności zwierząt.

Poza tym $w$ oddzielnych seriach eksperymentów ustalono, że nie istnieje zależność między tempem wydalania OTC w moczu a intensywnością fluorescencji kości badanych osobników. Stwierdzono także, iż optymalna dawka OTC wynosi $20 \mathrm{mg} / \mathrm{kg}$ wagi ciała. Intensywność fluorescencji jest podobna u zwierząt zabitych w 6-24 godzin po wstrzyknięciu OTC, a zniża się dopiero gdy czas ten wynosi 67 godz. (Tabela 3). Charakter obserwowanych zmian wiekowych jest podobny u gryzoni w wieku 14 do 34 dni. 